\title{
On the border effect in the Regional Comprehensive Economic Partnership ( RCEP)
}

\author{
TU Thuy Anh and CHU Thi Mai Phuong
}

Foreign Trade University (Nietnam)

\begin{abstract}
This paper analyses determinants of trade among RCEP negotiating countries with focus on the border effect. An extended gravity model has been fitted to RCEP trade data. The empirical findings are generally consistent with the theory. We find evidence on the existence of the border effects within RCEP negotiating countries. The paper also shows that being a member of ASEAN does improve trade flows of trading partners that may reinforce the central role of ASEAN in regional negotiation process of not only RCEP but also TPP.
\end{abstract}

Research for this paper was funded by the Swiss Secretariat for Economic Affairs (SECO) under a partnership agreement with the World Trade Institute of the University of Bern, Switzerland.

Disclaimer: These papers have not been formally edited. Citations should refer to a "SECO Working Paper", with appropriate reference made to the author $(s)$. 


\section{On the border effect in the Regional Comprehensive Economic Partnership (RCEP)}

TU Thuy Anh and CHU Thi Mai Phuong

\section{Introduction}

Nowadays, ASEAN is an important trade body largely because it achieved regional and domestic political stability and used this platform to energize its economies. This would have seemed fanciful at ASEAN's birth in 1967 but, in retrospect, the region has followed skillful approaches to political and economic integration ever since.

Recently, ASEAN finds itself at the epicenter of two of the world's most important regional trade policy initiatives: the Trans Pacific Partnership (TPP) and the Regional Comprehensive Economic Partnership (RCEP). The TPP and RCEP processes are not

only dynamic in their own right, but are examples of competitive liberalization-they stimulate each other's progress. The current TPP negotiations gathered steam when the United States committed to join the existing P4 group, in part for fear of being left out of Asia's dynamic economic future. The RCEP negotiations, in turn, intensified with the expansion and growing ambition of the TPP effort. And the negotiations still have a long way to expand: neither, for now, envisions bringing together the region's two largest economies, the United States and China. In this sense, both initiatives are intermediate steps toward a more distant future system that covers the entire region and perhaps economies beyond it.

This paper focuses on the Regional Comprehensive Economic Partnership (RCEP) - a FTA negotiation that has been developed among 16 countries: the 10 members of ASEAN (Brunei, Cambodia, Indonesia, Laos, Malaysia, Myanmar, the Philippines, Singapore, Thailand, and Viet Nam) and the six countries with which ASEAN has 
existing Free Trade Agreements (FTAs) - Australia, China, India, Japan, Korea, and New Zealand. The participants in the RCEP FTA negotiations have a total population of over 3 billion people and a trade share estimated at around 27 per cent of global trade (WTO, 2012), covering GDP of around \$US21 trillion (IMF, 2013). RCEP, once successfully negotiated, may generate high benefits for the participants; but it faces many challenges. At this time, it is important to understand determinants of trade of RCEP countries. Among these determinants, trade resistance such as distance, adjacency (so called the border effect).... is of special interest.

Regarding the border effect, in a seminal paper, McCallum (1995) found that Canadian provinces trade up to 22 times more with each other than with U.S. states. This astounding result, also known as the international border effect, has led to a large literature on the trade impediments associated with international borders. More recently, Anderson and van Wincoop (2003) revisited the U.S.-Canadian border effect with new micro-founded estimates. Although they are able to reduce the border effect considerably, there is widespread consensus that the international border remains a large impediment to trade. A parallel, smaller literature has documented that border effects also exist within a country, known as the domestic border effect. For example, Wolf (2000) finds that trade within individual U.S. states is significantly larger than trade between U.S. states even after he controls for economic size, distance and a number of additional determinants. Likewise, Nitsch (2000) finds that domestic trade within the average European Union country is about ten times larger than trade with another EU country.

Among 12 RCEP countries that are under investigation, 7 countries share common border. Understanding economics impacts of this border as well as of other trade resistance variables are important for future negotiation and integration strategy of RCEP countries. 
The paper is organized as follows: section 2 summarizes main features of RCEP, section 3 outlines theoretical framework for gravity model taking into account the significance of the border effect, section 4 introduces the econometric model and estimation strategy, section 5 describes data and present descriptive analysis of the data, section 6 shows estimation results. Final section concludes the paper.

\section{RCEP: A brief overview}

RCEP negotiations were launched by the Leaders of the 16 participating countries in the margins of the East Asia Summit on 20 November 2012. Leaders announced that RCEP would be "a modern, comprehensive, high-quality and mutually beneficial economic partnership agreement establishing an open trade and investment environment in the region to facilitate the expansion of regional trade and investment and contribute to global economic growth and development”.

The participants have developed Guiding Principles for the negotiations. These were approved by Economic Ministers on 30 August 2012 and endorsed by Leaders and provide a roadmap for negotiators.

RCEP is a significant step in the evolution of trade policy frameworks in East Asia over the past decade. RCEP's history reaches back some 10 years, starting as a study process for an FTA between ASEAN, China, Japan, and Korea (known as ASEAN+3). This was complemented from 2007 with a parallel study process for an ASEAN+6 FTA, which included the ASEAN+3 partners plus Australia, India, and New Zealand. Both these study processes concluded in 2011 following which ASEAN put forward the RCEP concept.

Following a preparatory process, the participating countries began formal negotiations in May 2013. RCEP will cover trade in goods, trade in services, investment, economic and 
technical cooperation, intellectual property, competition, dispute settlement/legal and institutional issues and other issues to be identified during the course of negotiations.

The first round of RCEP negotiations was held from 9-13 May in Brunei Darussalam. Good progress was made towards meeting the target of concluding the negotiations by the end of 2015. The Brunei meetings took place in a positive and constructive atmosphere. Three working groups were established - on Goods, Services and Investment. Discussions included how to plan the way forward in these three areas. The parties also had an initial exchange of views in the other areas covered by the Guiding Principles. Overall, the ground was prepared for further progress to be made at Round 2.

Negotiations for the RCEP FTA continued to make good progress at Round 2, in Brisbane from 23-27 September 2013. Discussion continued on the structure and elements of the services chapter, with initial views exchanged on possible market access commitments in a range of areas of interest to the participants. In goods, among other things dedicated sessions were convened on Customs Procedures, Rules of Origin, and useful initial exchanges on the modalities for tariff negotiations and on non-tariff barriers to market access. Sub-Working Groups were established on Customs Procedures and Rules of Origin. Discussions occurred on elements to be covered in investment. Discussions also took place on competition policy, intellectual property, economic and technical cooperation and dispute settlement. Information was also presented on other issues that could be included in the RCEP FTA, on which further consideration will be needed. In addition, a seminar on Competition Policy was held with presentations by international speakers.

The third round of RCEP negotiations was held in Kuala Lumpur 20 - 24 January 2014. At the meeting the 16 participating countries continued technical work on trade in goods, trade in services, and investment. 
In Trade in goods, participating countries had a constructive discussion on the modalities for the tariff negotiations, on non-tariff measures, Standards, Technical Regulations and Conformity Assessment Procedures (STRACAP), Sanitary and Phytosanitary Measures (SPS) as well as on Customs Procedures and Trade Facilitation (CPTF) and Rules of Origin (ROO).

On Trade in services, participating countries discussed the structure and elements of the RCEP Services Chapter, areas of market access interests and a number of specific issues at good length.

On Investment, participating countries exchanged views on investment modalities and deliberated further on the elements for the RCEP Investment Chapter. In order to advance negotiations on the broad range of issues four further working groups were established, on Intellectual Property, Competition, Economic and Technical Cooperation, and Dispute Settlement. Some participating countries made presentations on other issues that may be identified and mutually agreed in the course of negotiations for inclusion among the issues to be covered by RCEP.

Two Seminars were held on the sidelines of the round. Malaysia and Japan presented on a broad range of Intellectual Property (IP) issues, including how IP supports trade and investment. Australia organized a seminar on the cross cutting areas of Services and Investment.

The 4th round of RCEP negotiations took place in Nanning, China 31 March - 4 April 2014. The participating countries continued intensive discussion on a range of issues to advance the negotiations.

Participating countries engaged on the development of trade in goods texts, intensified consideration of modalities to be used for tariff negotiations and continued discussions on non-tariff measures, Standards, Technical Regulations and Conformity Assessment 
Procedures (STRACAP), Sanitary and Phytosanitary Measures (SPS) as well as on Customs Procedures and Trade Facilitation (CPTF) and Rules of Origin (ROO).

On Trade in services, participating countries deliberated on the elements of text, the scope of provisions, the approach to scheduling market access commitments, market access commitments, and a number of other specific issues. On Investment, participating countries engaged in discussions on text, and an in-depth discussion on the elements including investment modalities.

At the Nanning meeting, the new working groups n Intellectual Property, Competition, and Economic and Technical Cooperation commenced their work. Other issues of particular interest to a number of RCEP participating countries were discussed. Experts met to discuss Dispute Settlement and broader legal and institutional issues. A formal working group will be established to continue these discussions at the next meeting.

The 5th RCEP negotiation round will be held on 23-27 June 2014 in Singapore.

\section{Theoretical motivation for border effect in international trade}

Going back to 1995, McCallum compared within-Canada and US-Canada trade using the following regression:

$$
\ln X_{i j}=\alpha+\beta_{1} \ln Y_{i}+\beta_{2} \ln Y_{j}+\rho \ln d_{i j}+\gamma \delta_{i j}+\varepsilon_{i j}
$$

where $\mathrm{Xij}$ is exports from region $\mathrm{i}$ to region $\mathrm{j}, \mathrm{Yi}$ and $\mathrm{Yj}$ are gross domestic production in regions $\mathrm{i}$ and $\mathrm{j}$, dij is the distance between regions $\mathrm{i}$ and $\mathrm{j}$, and $\delta \mathrm{ij}$ is a dummy variable equal to one for inter-provincial trade and zero for state-province trade. For the year 1988 McCallum estimated this equation using data for all 10 provinces and for 30 states that account for $90 \%$ of U.S.-Canada trade.

Results of McCallum regression are that: $\hat{\beta}_{1}$ and $\hat{\beta}_{2} \approx 1 ; \hat{\rho}<0$ meaning a negative effect of distance; $\hat{\gamma} \approx 3$ meaning that border effect exists. Intranational trade is about 22 times larger than international trade! Hence, one needs to introduce trade barriers into the 
analysis! However, this implies that prices may differ across countries, meaning that there is in need of more microfoundation, including prices in the Gravity equation.

For that purpose, let consider the simple trade model as follows. Assume that:

$X_{k}^{i j}$ is export from i to j of good $\mathrm{k}$;

$c_{k}^{i j}$ is consumption in $\mathrm{j}$ of good $\mathrm{k}$ (produced in $\left.\mathrm{i}\right), X_{k}^{i j}=p_{k}^{i j} c_{k}^{i j}$;

$N^{i}$ is number of products produced in country i;

$p^{i}$ is F.O.B. price of goods produced in country $\mathrm{i}$;

$p^{i j}=T C^{i j} p^{i}$ is C.I.F. price of goods produced in i and sold in $\mathrm{j}$, TC is the trade cost, $T C^{i j} \geq 1, T C^{i i}=1$.

Assume each good is produced with the sane technology, hence

$$
p_{k}^{i j}=p^{i j}, \forall k \Rightarrow c_{k}^{i j}=c^{i j}, \forall k
$$

Consumers’ problem is to

$$
\max _{c^{i j}} U^{j}=\left[\sum_{i=1}^{I} N^{i}\left(c^{i j}\right)^{\frac{\sigma-1}{\sigma}}\right]^{\frac{\sigma}{\sigma-1}} \text { s.t. } \sum_{i=1}^{I} N^{i} p^{i j} c^{i j}=Y^{j} \quad(\text { where } \sigma>1)
$$

The solution takes the form:

$$
X^{i j}=N^{i}\left(\frac{p^{i j}}{p^{j}}\right)^{1-\sigma} Y^{j}=\frac{Y^{i} Y^{j}}{\left(p^{i}\right)^{\sigma} \bar{y}}\left(\frac{T C^{i j}}{p^{j}}\right)^{1-\sigma} \text { where } P^{j}=\left[\sum_{i=1}^{I} N^{i}\left(p^{i j}\right)^{1-\sigma}\right]^{\frac{1}{1-\sigma}} \text { and } \bar{y}=\frac{Y^{i}}{N^{i} p^{i}}
$$

Gravity equation is derived as $X^{i j}=\frac{Y^{i} Y^{j}}{\left(p^{i}\right)^{\sigma} \bar{y}}\left(\frac{T C^{i j}}{p^{j}}\right)^{1-\sigma}$

The estimating equation therefore is:

$\Delta \ln X_{i j}=\Delta \ln \left(Y_{i} Y_{j}\right)+(1-\sigma) \Delta \ln T C^{i j}-\sigma \Delta \ln p^{i}+(\sigma-1) \Delta \ln p^{j}+\varepsilon^{i j}$

Empirically, trade costs (TC) are measured by distance and adjacency. We will use these variables instead of TC when estimating the models. 


\section{Econometric model and estimation strategy}

We start by estimating determinants of trade of RCEP countries adopting the conventional gravity model as follows:

Model 1:

$\ln (T)_{i j}^{t}=\beta_{1}+\beta_{2} \operatorname{lnGDP}_{i}^{t}+\beta_{3} \operatorname{lnGDP} P_{j}^{t}+\beta_{4} \ln \operatorname{Distance}_{i j}+\beta_{5} \operatorname{lnrate}_{i j}^{t}+\beta_{6} D_{i j}+\varepsilon_{i j}^{t}$

where:

$\ln (T)_{i j}^{t}$ is (the log of) trade volume between country i and country $\mathrm{j}$ at time t;

$\ln G D P_{i}^{t}$ is (the log of) GDP country i at time t;

$\ln G D P_{j}^{t}$ is (the log of) GDP country $\mathrm{j}$ at time t;

lnDistance $_{i j}$ is distance between country i's capital and country j's one;

lnrate $_{i j}^{t}$ is exchange rate of country $\mathrm{i} /$ exchange rate of country $\mathrm{j}$ at time $\mathrm{t}$

$\mathrm{D}$ is dummy variable that is one if country $\mathrm{I}$ and country $\mathrm{j}$ share a border and zero otherwise.

The dependent variable is a bilateral trade flow. It measures the total value of goods exported and imported between country i to country j. Countries are expected to trade more with each other the larger they are. This is measured by gross domestic product of exporter and importer. The volume of trade between two countries depends not only on their size and the distance from each other, but also on the size and the distance to other trading partners. The distance variable indicates that more distant countries tend to trade less as transportation costs rise.

Estimation result of model (1) will shed light on key determinants of trade between RCEP countries, and pointing out the possible role of exchange rate and especially trade resistance variable on regional trade.

Besides the distance variable, Helliwell (1997: 169-70) explains that the economic remoteness variables play an important role as well. They are defined as 


$$
\text { remoteness }_{i j}=\left(\sum_{j, j \neq i} \frac{G D P_{j}}{\text { distance }_{i j}}\right)^{-1}
$$

Other control variables that are relevant to explain trade flow are also considered in the model: ASEAN is dummy variable that is one if country $\mathrm{i}$ and $\mathrm{j}$ are both Asean members and zero otherwise; so coefficient of ASEAN measure intra ASEAN trade; Crisis is dummy variable that is one if country I is affected from financial crises in year $\mathrm{t}$ and zero otherwise. Crisis data are taken from Laeven and Valencia (2012). According to Laeven and Valencia, Vietnam is only affected by financial crisis in 2007. This extended gravity equation is written as follows:

\section{Model 2:}

$$
\begin{aligned}
\ln (T)_{i j}^{t}=\beta_{1} & +\beta_{2} \ln G D P_{i}^{t}+\beta_{3} \ln G D P_{j}^{t}+\beta_{4} \operatorname{lnDistance~}_{i j}+\beta_{5} \text { lnrate }_{i j}^{t}+\beta_{6} D \\
& +\beta_{7} \text { lnremoteness }_{i j}+\beta_{8} \text { Asean }_{i j}+\beta_{9} \text { Crisis }_{i t}+\varepsilon_{i j}^{t}
\end{aligned}
$$

If the benchmark models show that the border effect exists in the region, we will estimate the alternative model that take into account the prices differences in the countries factors that explain the border effects of the region (model 3 and 4). Price heterogeneity in the model is captured by two alternatives: (i) taking the GDP deflator into account (model 3.1 and 4.1), and (ii) considering country fixed effects (model 3.2 and 4.2). We investigate the case of dependent variable to be both total trade flows and exports alone to make it consistent with the theory depicted above.

Model 3:

$\ln (T)_{i j}^{t}=\beta_{1}+\beta_{2} \ln G D P_{i}^{t}+\beta_{3} \ln G D P_{j}^{t}+\beta_{4} \ln$ istance $_{i j}+\beta_{5} \operatorname{lnrate}_{i j}^{t}+\beta_{6} D+$

$\beta_{7}$ lnremoteness $_{i j}+\beta_{8}$ Asean $_{i j}+\beta_{9}$ Crisis $_{i t}+\beta_{10} \ln G D P D_{i}^{t}+\beta_{11} \ln G D P D_{j}^{t}+\varepsilon_{i j}^{t}$

Model 4:

$\ln (X)_{i j}^{t}=\beta_{1}+\beta_{2} \ln G D P_{i}^{t}+\beta_{3} \ln G D P_{j}^{t}+\beta_{4} \operatorname{lnDistance}_{i j}+\beta_{5} \operatorname{lnrate}_{i j}^{t}+\beta_{6} D+$ $\beta_{7}$ lnremoteness $_{i j}+\beta_{8}$ Asean $_{i j}+\beta_{9}$ Crisis $_{i t}+\beta_{10} \ln G D P D_{i}^{t}+\beta_{11} \ln G D P D_{j}^{t}+\varepsilon_{i j}^{t}$ 
where:

$\ln (X)_{i j}^{t}$ is (the log of) total export from country i to country at time t.

$\ln G D P D_{i}^{t}$ is (the log of) GDP deflators of country i at time t.

$\ln G D P D_{j}^{t}$ is (the log of) GDP deflators of country $\mathrm{j}$ at time t.

\section{Description of data}

The import, export data are taken from trademap. The distance data is taken from notre planete.info. Remaining data are taken from unstats.un.org.

Trade volume between Vietnam and partners from 2001 -2013

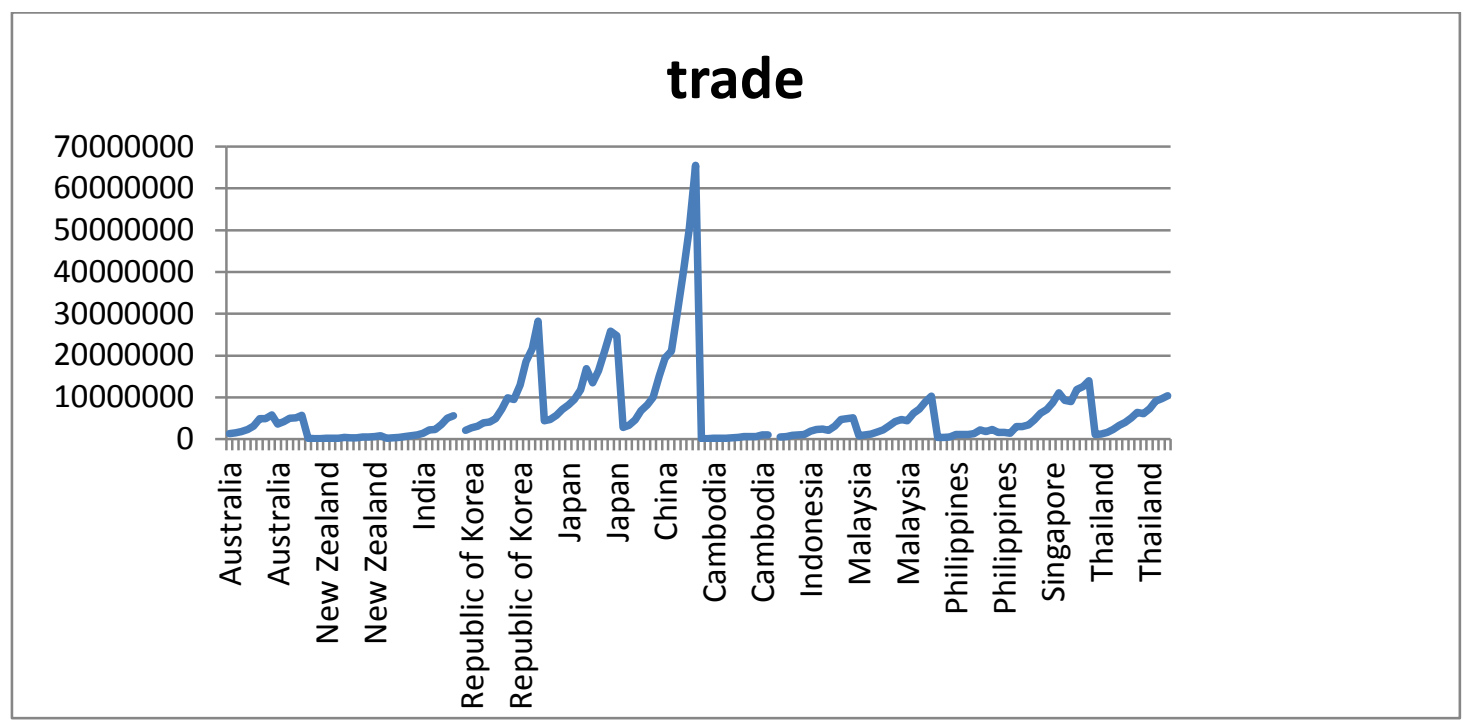

Trade volume between Vietnam and RCEP partners are depicted in Figure 1. It is clear that China is the most important trade partner of Vietnam in the region, followed by Korea and Japan. Over the period of 2001-2012, these three East Asian partners account for aboutt $60 \%$ of total trade of Vietnam with the RCEP region.

Our sample is made of ASEAN+6 over thirteen years. This gives a maximum of $13 * 12 *$ $12=1872$ individual observations. Summary statistics for the data are provided in Table 1. 
Table 1: Summary statistics

\begin{tabular}{|l|l|l|l|l|l|}
\hline Variable & Obs. & Mean & Std. Dev. & Min & Max \\
\hline lnT & 1868 & 15.26898 & 2.168151 & 6.632002 & 19.66171 \\
\hline Lngdpi & 1728 & 19.43556 & 1.722835 & 15.19975 & 22.84653 \\
\hline lngdpj & 1727 & 19.54261 & 1.693592 & 15.19975 & 22.84653 \\
\hline lnrate & 1728 & -0.0327739 & 4.895478 & -9.978851 & 9.978851 \\
\hline Lndist & 1872 & 8.15082 & 0.7851557 & 5.739793 & 9.446676 \\
\hline lnX & 1868 & 14.44803 & 2.3887 & 4.8978 & 19.0542 \\
\hline lngdpdi & 1728 & 4.70515 & 0.25808 & 4.00810 & 5.3485 \\
\hline lngdpdj & 1728 & 4.7025 & 0.2549 & 4.00810 & 5.3485 \\
\hline lnremoteness & 1872 & -8.4896 & 1.3381 & -10.4049 & -6.6292 \\
\hline
\end{tabular}

To get a broad idea about the model, we construct the correlation matrix among variables.

Results are as follows:

In the table 2, correlations between GDPi, GDPj and trade are large and positive. Correlation between distance and trade is small and negative. Exchange rate and trade is very weakly correlated. Correlation between GDPi, GDPj, GDPDi, GDPDi and export are large and positive. Correlation between distance and export is small and negative. In general, correlation between the independent variables are small, one hence should not worry about perfect multicollinearity. 
Table 2: Correlations matrix of the main variables

\begin{tabular}{|l|l|l|l|l|l|l|l|l|l|}
\hline & lnT & lngdpi & lngdpj & lnrate & lndistance & lngdpdi & lngdpdj & lnX & lnremoteness \\
\hline LnT & 1 & & & & & & & & \\
\hline Lngdpi & 0.596 & 1 & & & & & & & \\
\hline Lngdpj & 0.541 & -0.025 & 1 & & & & & & \\
\hline Lnrate & 0.016 & 0.198 & -0.191 & 1 & & & & & \\
\hline lndistance & -0.118 & 0.181 & 0.2009 & 0.013 & 1 & & & & \\
\hline lngdpdi & 0.225 & 0.187 & 0.208 & -0.044 & -0.091 & 1 & & & \\
\hline lngdpdj & 0.226 & 0.204 & 0.1889 & 0.041 & -0.087 & 0.747 & 1 & & \\
\hline lnX & 0.965 & 0.662 & 0.4452 & 0.072 & -0.078 & 0.207 & 0.209 & 1 & \\
\hline lnremoness & 0.024 & -0.075 & 0.006 & -0.277 & -0.194 & 0.044 & 0.233 & -0.01 & 1 \\
\hline
\end{tabular}




\section{The estimation results}

The paper uses several dummy variables, so we use the GLS estimation for the Random Effect model. Models are estimated by using robust variance procedure.

Table 3: Estimation results of total trade models

\begin{tabular}{|c|c|c|c|c|}
\hline \multirow[b]{2}{*}{ Independent variables } & \multicolumn{4}{|c|}{ Dependent variable: $\operatorname{LnT_{ij}^{t}}$} \\
\hline & Model 1 & Model 2 & Model 3.1 & Model 3.2 \\
\hline $\operatorname{LnGDP_{i}^{t}}$ & $\begin{array}{c}0.6965^{* * * *} \\
(0.000)\end{array}$ & $\begin{array}{c}0.7562^{* * *} \\
(0.000)\end{array}$ & $\begin{array}{c}0.8215^{* * *} \\
(0.000)\end{array}$ & $\begin{array}{c}0.5965^{* * *} \\
(0.000)\end{array}$ \\
\hline$L N G D P_{j}^{t}$ & $\begin{array}{c}0.7688^{* * *} \\
(0.000)\end{array}$ & $\begin{array}{c}0.7848^{* * *} \\
(0.000)\end{array}$ & $\begin{array}{c}0.8320^{* * *} \\
(0.000)\end{array}$ & $\begin{array}{c}0.6966 * * * \\
(0.000)\end{array}$ \\
\hline LnDistance $_{i j}$ & $\begin{array}{c}-0.8449 * * * \\
(0.000)\end{array}$ & $\begin{array}{c}-0.7648^{* * *} \\
(0.000)\end{array}$ & $\begin{array}{c}-0.7433^{* * *} \\
(0.000)\end{array}$ & $\begin{array}{c}-3.9984 * * * \\
(0.001)\end{array}$ \\
\hline Lnrate $_{i j}^{t}$ & $\begin{array}{c}-0.0245^{* * *} \\
(0.000)\end{array}$ & $\begin{array}{c}-0.0336 * * * \\
(0.000)\end{array}$ & $\begin{array}{c}-0.0335^{* * *} \\
(0.000)\end{array}$ & $\begin{array}{l}0.0542 \\
(0.247)\end{array}$ \\
\hline$D_{i j}$ (boder effect) & $\begin{array}{c}0.0587^{*} \\
(0.100)\end{array}$ & $\begin{array}{c}0.0677^{*} \\
(0.100)\end{array}$ & $\begin{array}{c}0.2039 \\
(0.000) \\
\end{array}$ & $\begin{array}{c}0.1847^{*} \\
(0.100)\end{array}$ \\
\hline lnremoteness $_{i j}$ & & $\begin{array}{c}-0.0332 * * * \\
(0.000)\end{array}$ & $\begin{array}{c}-0.0176^{*} \\
(0.052)\end{array}$ & $\begin{array}{c}-22.546^{* * *} \\
(0.000)\end{array}$ \\
\hline Asean $_{i j}$ & & $\begin{array}{c}0.3592^{* * *} \\
(0.000)\end{array}$ & $\begin{array}{c}0.5809 * * * \\
(0.000)\end{array}$ & $\begin{array}{c}0.0471 \\
(0.253) \\
\end{array}$ \\
\hline Crisis $_{i t}$ & & $\begin{array}{c}-0.2598 * * * \\
(0.000)\end{array}$ & $\begin{array}{c}-0.2423^{* * *} * \\
(0.000)\end{array}$ & $\begin{array}{c}-0.0947 * * * \\
(0.007)\end{array}$ \\
\hline $\ln G D P D_{i}^{t}$ & & & $\begin{array}{c}-0.3035^{* * *} \\
(0.000)\end{array}$ & \\
\hline $\ln G D P D_{j}^{t}$ & & & $\begin{array}{c}-0.2729^{* * *} \\
(0.000)\end{array}$ & \\
\hline _const & $\begin{array}{l}-6.3859 \\
(0.000)\end{array}$ & $\begin{array}{c}-8.7967 * * * \\
(0.000)\end{array}$ & $\begin{array}{c}-8.4387 * * * \\
(0.000)\end{array}$ & $\begin{array}{c}-207.06^{* * *} \\
(0.000)\end{array}$ \\
\hline $\mathrm{N}$ & 1462 & 1462 & 1462 & 1462 \\
\hline No. of id & 122 & 122 & 122 & \\
\hline Type & $\mathrm{RE}$ & $\mathrm{RE}$ & $\mathrm{RE}$ & $\begin{array}{l}\text { OLS country } \\
\text { fixed effect }\end{array}$ \\
\hline Reg & xtgls & xtgls & xtgls & reg \\
\hline Multicollinearity & no & no & no & no \\
\hline Heterosdasticity & no & no & no & no \\
\hline
\end{tabular}




\begin{tabular}{|c|c|c|c|c|}
\hline AR(1) & no & no & no & no \\
\hline $\begin{array}{c}\text { cross -sectional } \\
\text { dependent }\end{array}$ & no & no & no & no \\
\hline $\begin{array}{l}\text { Normal distribution of } \\
\text { residual }\end{array}$ & yes & yes & yes & yes \\
\hline
\end{tabular}

Note: All estimates are obtained by robust standard errors procedures; *, **and *** are represent that the parameters estimated are significant at the 10, 5 and 1 percent level respectively; The numbers in parentheses are p-value.

Robustness tests are carried on and the models pass all the diagnostic tests as: multicollinearity, autocorrelation, cross -sectional dependent, normal distribution of residual.

\section{Estimation results of model 1 and 2:}

The coefficient of GDP country $\mathrm{i}$ is significant at one percent and equal to 0.6965, indicating that increase $1 \%$ in national income leads to increase $0.6965 \%$ in trade volume. When controlling for remoteness, intra-ASEAN trade and impacts of crisis, this impacts of own GDP on trade increases to $0.7562 \%$.

The coefficient of the trading partners' GDP is statistically significant and equal to 0.7688 that means one percent increase in the trading partners' income will boost 0.7688 percent in trade volume. Additional controlling variables increase this impact to $0.7848 \%$.

The coefficient of distance is significant and equal to -0.8449 indicating that an increase in distance leads to a decrease in the trade volume. Specifically, one percent increase in distance will decrease 0.8449 percent in trade volume. Additional controlling variables decrease this negative impact to $0.7648 \%$.

As for bilateral real exchange rate impact, the coefficient of the bilateral real exchange rate is statistically significant in model and equal to -0.0245 indicating that an increase in 
bilateral real exchange rate leads to a decrease in the trade volume. Additional controlling variables increase this negative impact to $0.0336 \%$.

The coefficient of ASEAN is statistically significant equal to 0.359 , that means countries are member of ASEAN have larger trade volume than countries are not member of ASEAN. And the coefficient of Crisis is statistically significant equal to -0.2598 shows that trade of the countries affected by the crisis is $\exp (0.2598)=1.2966$ smaller than countries that are not affected by crisis.

The coefficient of the remoteness between country $i$ and country $j$ is statistically significant and equal to -0.0332 that means one percent increase the remoteness will make trade volume reduce by 0.0332 percent.

The coefficient of the border effect is statistically significant and equal to 0.0587 , that means countries sharing the common border will have trade value that is $\exp (0.0587)=$ 1.0604 times than that of the countries that do not have common borders. Additional controlling variables increase this positive impact to $\exp (0.0677)=1.07$. This result suggests that we have to estimate the model that control for price differences across countries. Model 3 deals with this issue by controlling for GDP deflators of the underlying countries, while model 4 captures also country fixed effects.

\section{Estimation results of model 3.1 and 3.2:}

The controlled variables still affect trade volume in the same direction as depicted in the benchmark regression, that are consistent with the theory. Interestingly, border effects are significant at $10 \%$ (model 3.2) and relatively increase: countries sharing the common border will have trade value that is $\exp (0.1847)=1.202858$ times than that of the countries that do not have common borders.

Although the sign (of the coefficient of GDP deflator $\mathrm{j}$ ) and the size of the coefficients of GDP deflators I and $\mathrm{j}$ are not consistent to the theory, these coefficients are significant at one percent. This remains a weakness of the paper. We plan to control for price 
heterogeneity by following Anderson and van Wincoop (2003) procedure in the next version of the paper.

\section{Estimation results of model 4.1 and 4.2:}

Final empirical procedure is carried out to explain the exports as the dependent variable that is consistent with the theory introduced previously. Model 4.1 controls price heterogeneity by GDP deflators alone, while model 4.2 also takes into account the country fixed effect. All coefficients of GDP deflators are statistically significant at $1 \%$, and the demand elasticity sigma is successfully estimated to be 1.1371 .

Table 4: Estimation results of export models

\begin{tabular}{|c|c|c|}
\hline \multirow[b]{2}{*}{ Independent variables } & \multicolumn{2}{|c|}{ Dependent variable: $\operatorname{Ln} X_{i j}^{t}$} \\
\hline & Model 4.1 & Model 4.2 \\
\hline $\operatorname{LnGDP} P_{i}^{t}$ & $\begin{array}{c}0.9436 * * * \\
(0.000)\end{array}$ & $\begin{array}{c}1.2025 * * * \\
(0.000)\end{array}$ \\
\hline$L N G D P_{j}^{t}$ & $\begin{array}{c}0.8206^{* * *} \\
(0.000)\end{array}$ & $\begin{array}{c}1.3064^{* * * *} \\
(0.000)\end{array}$ \\
\hline LnDistance $_{i j}$ & $\begin{array}{c}-0.6177 * * * \\
(0.000)\end{array}$ & $\begin{array}{l}-1.331 \\
(0.437)\end{array}$ \\
\hline Lnrate $_{i j}^{t}$ & $\begin{array}{c}-0.0218^{* * *} \\
(0.000)\end{array}$ & $\begin{array}{l}0.0557 \\
(0.391)\end{array}$ \\
\hline$D_{i j}$ (boder effect) & $\begin{array}{c}0.2021^{* * *} \\
(0.000)\end{array}$ & $\begin{array}{c}0.2023 * * * \\
(0.000)\end{array}$ \\
\hline lnremoteness $_{i j}$ & $\begin{array}{c}0.0602 * * * \\
(0.000)\end{array}$ & $\begin{array}{c}-10.7579 * \\
(0.092)\end{array}$ \\
\hline Asean $_{i j}$ & $\begin{array}{c}0.6799 * * * \\
(0.000)\end{array}$ & $\begin{array}{c}0.0885 \\
(0.171) \\
\end{array}$ \\
\hline Crisis $_{i t}$ & $\begin{array}{c}-0.4553 * * * \\
(0.000)\end{array}$ & $\begin{array}{c}-0.1528 * * * \\
(0.000)\end{array}$ \\
\hline $\ln G D P D_{i}^{t}$ & $\begin{array}{c}-0.4674^{* * *} \\
(0.000)\end{array}$ & $\begin{array}{c}-1.1371^{* * *} \\
(0.000)\end{array}$ \\
\hline $\ln G D P D_{j}^{t}$ & $\begin{array}{c}-0.2568 * * * \\
(0.000) \\
\end{array}$ & $\begin{array}{c}-0.9343^{* * *} \\
(0.000) \\
\end{array}$ \\
\hline _const & $\begin{array}{c}-11.0124 \\
(0.000)\end{array}$ & $\begin{array}{c}-112.68^{*} \\
(0.061)\end{array}$ \\
\hline $\mathrm{N}$ & 1462 & 1462 \\
\hline
\end{tabular}




\begin{tabular}{|c|c|c|}
\hline No. of id & 122 & 122 \\
\hline Type & RE & OLS \\
\hline Reg & xtgls & reg \\
\hline Multicollinearity & no & no \\
\hline Heterosdasticity & no & no \\
\hline AR(1) & no & no \\
\hline cross -sectional dependent & no & no \\
\hline $\begin{array}{l}\text { Normal distribution of } \\
\text { residual }\end{array}$ & yes & yes \\
\hline
\end{tabular}

\section{Concluding remarks}

The extended gravity model fits RCEP trade data well. The empirical findings are generally consistent with the theory hence the findings are quite robust. The paper sheds light on the existence of the border effects with RCEP negotiating countries. This finding should provide useful inputs for RCEP countries' Leaders when negotiating RCEP. The paper also shows that being a member of ASEAN does improve trade flows of trading partners that may reinforce the central role of ASEAN in regional negotiation process of not only RCEP but also TPP.

One shortcoming of the paper is in estimating the elasticity of demand that is expected to be done in our next version of the paper when adopting Anderson and van Wincoop (2003) estimation procedure. 


\section{References}

Anderson, J., van Wincoop, E., 2003. Gravity with Gravitas: A Solution to the Border Puzzle. American Economic Review 93, pp. 170-192.

Anderson, J., van Wincoop, E., 2004. Trade Costs. Journal of Economic Literature 42, pp. 691-751.

Bandyopadhyay, S., Coughlin, C., Wall, H., 2008. Ethnic Networks and US Exports. Review of International Economics 16, pp.199-213.

Blum, M., Goldfarb, A., 2006. Does the Internet Defy the Law of Gravity? Journal of International Economics 70, pp. 384-405.

Cassey, A., 2011. State Foreign Export Patterns. Southern Economic Journal, forthcoming.

Cassey, A., 2009. State Export Data: Origin of Movement vs. Origin of Production. Journal of Economic and Social Measurement 34, pp. 241-268.

Chaney, T., 2008. Distorted Gravity: The Intensive and Extensive Margins of International Trade. American Economic Review 98, pp. 1707-1721.

Chen, N., 2004. Intra-National versus International Trade in the European Union: Why Do National Borders Matter? Journal of International Economics 63, pp. 93-118.

Chen, N., Novy, D., 2008. International Trade Integration: A Disaggregated Approach. CEPR Discussion Paper \#7103.

Combes, P., Lafourcade, M., Mayer, T., 2005. The Trade-Creating Effects of Business and Social Networks: Evidence from France. Journal of International Economics 66, pp. 1-29.

Coughlin, C., 2004. The Increasing Importance of Proximity for Exports from U.S. States. Federal Reserve Bank of St. Louis Review 86, pp. 1-18.

Coughlin, C., Mandelbaum, T., 1991. Measuring State Exports: Is There a Better Way? Federal Reserve Bank of St. Louis Review 73, pp. 65-79.

Coughlin, C., Wall, H., 2003. NAFTA and the Changing Pattern of State Exports. Papers in Regional Science 82, pp. 427-450.

Cronovich, R., Gazel, R., 1999. How Reliable Are the MISER Foreign Trade Data? Unpublished manuscript.

Eaton, J., Kortum, S., 2002. Technology, Geography and Trade. Econometrica 70, pp. 1741-1779.

Fally, T., Paillacar, R., Terra, C., 2010. Economic Geography and Wages in Brazil: Evidence from Micro-Data. Journal of Development Economics 91, pp. 155-168.

Head, K., Mayer, T., 2009. Illusory Border Effects: Distance Mismeasurement Inflates Estimates of Home Bias in Trade. In: The Gravity Model in International Trade: 
Advances and Applications. Editors: Bergeijk and Brakman, Cambridge University Press.

Helliwell, J., 1997. National Borders, Trade and Migration. Pacific Economic Review 2, pp. 165-185.

Helliwell, J., 1998. How Much Do National Borders Matter? Washington, D.C., Brookings Institution.

Helliwell, J., Verdier, G., 2001. Measuring Internal Trade Distances: A New Method Applied to Estimate Provincial Border Effects in Canada. Canadian Journal of Economics 34, pp. 1024-1041.

Hering, L., Poncet, S., 2010. Market Access and Individual Wages: Evidence from China. Review of Economics and Statistics 92, pp. 145-159.

Hillberry, R., Hummels, D., 2003. Intranational Home Bias: Some Explanations. Review of Economics and Statistics 85, pp. 1089-1092.

Hillberry, R., Hummels, D., 2008. Trade Responses to Geographic Frictions: A Decomposition Using Micro-Data. European Economic Review 52, pp. 527-550.

Hortaçsu, A., Martínez-Jerez, F., Douglas, J., 2009. The Geography of Trade in Online Transactions: Evidence from eBay and MercadoLibre. American Economic Journal: Microeconomics 1, pp. 53- 74.

Levinson, M., 2006. The Box: How the Shipping Container Made the World Smaller and the World Economy Bigger. Princeton University Press.

McCallum, J., 1995. National Borders Matter: Canada-U.S. Regional Trade Patterns. American Economic Review 85, pp. 615-623.

Melitz, M., 2003. The Impact of Trade on Intra-Industry Reallocations and Aggregate Industry Productivity. Econometrica 71, pp. 1695-1725.

Melitz, M., Ottaviano, G., 2008. Market Size, Trade, and Productivity. Review of Economic Studies 75, pp. 295-316.

Millimet, D., Osang, T., 2007. Do State Borders Matter for U.S. Intranational Trade? The Role of History and Internal Migration. Canadian Journal of Economics 40, pp. 93-126.

Nitsch, V., 2000. National Borders and International Trade: Evidence from the European Union. Canadian Journal of Economics 33, pp. 1091-1105.

Poncet, S., 2003. Measuring Chinese Domestic and International Integration. China Economic Review 14, pp. 1-21.

Rauch, J., Casella, A., 2003. Overcoming Informational Barriers to International Resource Allocation: Prices and Ties. Economic Journal 113, pp. 21-42. 
Rauch, J., Trindade, V., 2002. Ethic Chinese Networks in International Trade. Review of Economics and Statistics 84, pp. 116-130.

Rossi-Hansberg, E., 2005. A Spatial Theory of Trade. American Economic Review 95, pp. 1464-1491.

Smith, P., 1999. Are Weak Patent Rights a Barrier to U.S. Exports? Journal of International Economics 48, pp. 151-177.

Wei, S., 1996. Intra-National Versus International Trade: How Stubborn are Nations in Global Integration? NBER Working Paper \#5531.

Wolf, H., 2000. Intranational Home Bias in Trade. Review of Economics and Statistics 82, pp. 555-563.

Wolf, N., 2009. Was Germany Ever United? Evidence from Intra- and International Trade 1885-1933. Journal of Economic History 69, pp. 846-881.

Yi, K., 2010. Can Multistage Production Explain the Home Bias in Trade? American Economic Review 100, pp. 364-393. 